\title{
NOTE
}

\section{Quantitative estimates of demersal zooplankton abundance in Onslow Bay, North Carolina, USA}

\author{
Lawrence B. Cahoon ${ }^{1}$, Craig R. Tronzo ${ }^{2}$ \\ ${ }^{1}$ Department of Biological Sciences, University of North Carolina Wilmington, Wilmington, North Carolina 28403, USA \\ ${ }^{2}$ Oxford Laboratories, 1316 S. 5th St., Wilmington, North Carolina 28401 USA
}

\begin{abstract}
Demersal zooplankton were sampled by reentry trapping at 4 locations in Onslow Bay, North Carolina, USA, from 1983 to 1986 . Vertical plankton tows were also taken to compare the fauna in the water column with the demersal zooplankton. Demersal zooplankton are taxonomically distinct from the holozooplankton. Demersal zooplankton were captured in greater numbers at night and over sand substrates. Demersal zooplankton were approximately as abundant as holozooplankton ( 1 to $6 \times 10^{4}$ ind. $\mathrm{m}^{-2}$ ). Estimates of demersal zooplankton abundance in Onslow Bay are generally higher than those reported from other habitats. Demersal zooplankton are concentrated at the sediment-water interface, and are likely to be important prey for zooplanktivores in the continental shelf ecosystem off North Carolina.
\end{abstract}

Demersal zooplankton are distinguished from zooplankton that remain in the water column continuously, here termed 'holozooplankton', by their periodic association with benthic substrates (Alldredge \& King 1977 , Porter \& Porter 1977, Robichaux et al. 1981). Quantitative sampling of demersal zooplankton by methods suitable for holozooplankton sampling is therefore difficult. Because of their association with benthic substrates, specific methods have been developed for estimating demersal zooplankton abundance.

Demersal zooplankton appear to be widely distributed and associated with substrates ranging from mud and sand to rock and coral, but sampling has been restricted to shallow habitats. Reported total average abundances range from $10^{2}$ to $10^{3} \mathrm{~m}^{-2}$, but this range includes a preponderance of results from emergence trapping, which appears to include some holozooplankters and to undersample actual demersal zooplankton (Alldredge \& King 1980, Cahoon \& Tronzo 1988).

We present here the results of a study of demersal zooplankton abundance in Onslow Bay, North
Carolina, USA, that employed reentry trapping. Reentry trapping samples demersal zooplankton more accurately than other methods (Cahoon \& Tronzo 1988, Cahoon et al. 1992). We compared the abundance and taxonomic composition of demersal zooplankton with those of holozooplankton from the overlying water column. We also compared demersal zooplankton assemblages from several locations in Onslow Bay, by day and night, and at different times of the year from the same location. Our aim was to generate a more complete estimate of demersal zooplankton abundance in an extensive continental shelf ecosystem than previous studies have allowed.

Methods and materials. Onslow Bay is a portion of the southeastern U.S. continental shelf bounded by Capes Lookout and Fear and the Gulf Stream (Fig. 1). The continental shelf in Onslow Bay is approximately 60 to $110 \mathrm{~km}$ wide, and breaks at approximately $55 \mathrm{~m}$ (Menzies et al. 1966). Approximately $90 \%$ of the bottom in Onslow Bay is soft sediment habitat (Newton et al. 1971).

We sampled demersal zooplankton at 4 sites in Onslow Bay (Fig. 1). The ' 3 -mile' site is within $100 \mathrm{~m}$ of an artificial reef consisting of several ships and other debris. The bottom at this site $(14 \mathrm{~m})$ consists of patches of sand and exposed limestone rock with $<1 \mathrm{~m}$ relief. The ' 6 -mile' site is $19 \mathrm{~m}$ deep with a featureless coarse sand bottom. The '23-mile' site is a limestone ledge of up to $5 \mathrm{~m}$ relief at depths of 30 to $33 \mathrm{~m}$. The ledge provides substrate for dense populations of macroflora and macrofauna, including various sessile invertebrates and temperate reef fishes (Clavijo et al. 1989). The 'Deep' site is in $41 \mathrm{~m}$ of water with a flat, sandy bottom with scattered benthic macroflora. 


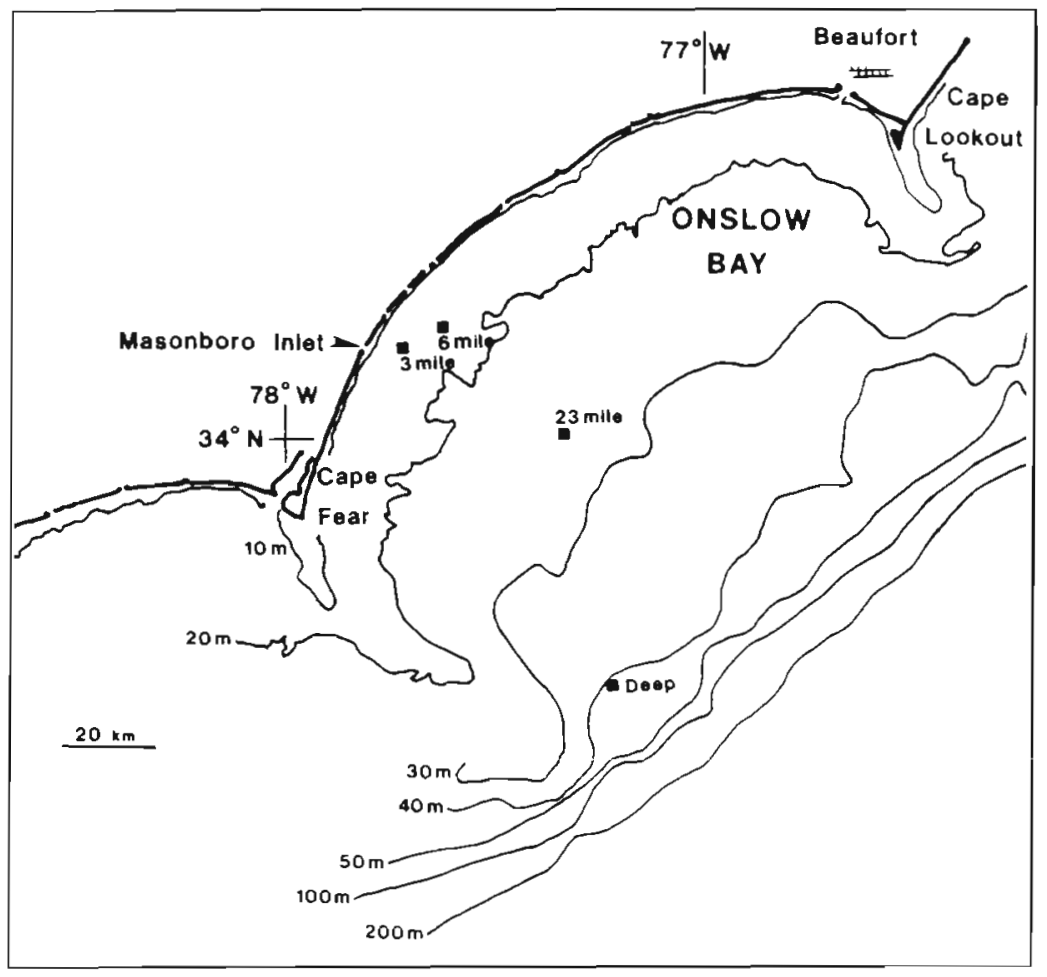

Fig. 1. Study sites in Onslow Bay off North Carolina, USA

on overnight trips. Zooplankton captured in these tows were bottled, fixed, and stained as above.

Zooplankton samples were identified to species whenever possible using published keys and consultation with taxonomic experts. Species lists are published elsewhere (Tronzo \& Cahoon 1989, Cahoon \& Tronzo 1990). Zooplankton are grouped here by higher taxa (family, order, etc.) to facilitate quantitative comparisons.

Results. The overall average abundance of demersal zooplankton at Onslow Bay sites during the period August 1983 to March 1986 was 18600 ind. $\mathrm{m}^{-2}$ (Table 1 ). The lowest average abundance occurred at the lowest temperature, but no clear seasonality was otherwise evident in the abundance data.

Demersal zooplankton were as abundant as holozooplankton sampled by vertical net tows on 4 occasions when direct comparisons were made (Table 1). However, percent similarity values [using higher taxa abundances and the percent similarity index of

Demersal zooplankton sampling commenced in August 1983 and continued through March 1986, as offshore diving opportunities were available. Demersal zooplankton were sampled by reentry traps that were deployed and retrieved by SCUBA divers. Reentry traps consisted of polyethylene trays $21 \times$ $21 \mathrm{~cm}$ with snap-top lids. These were filled with 11 of clean sand to an approximate depth of $2 \mathrm{~cm}$. Divers filled the traps with filtered seawater, carried them to the bottom with their lids attached, spread the traps along the bottom, and removed the lids. Lids were replaced and secured at the end of a deployment and the traps returned to the surface. Most trap deployments were made overnight. Reentry traps, usually 10 at a time, were placed or retrieved within $2 \mathrm{~h}$ of dawn or dusk.

The supernatant water in reentry traps was filtered through a $95 \mu \mathrm{m}$ mesh sieve, followed by at least 6 washings with fresh water to remove any animals from the sand in the reentry traps. Fresh water relaxed the animals, facilitating their quantitative removal. These samples were placed in labeled vials containing filtered seawater and fixed and stained in a $5 \%$ buffered formalin/Rose Bengal solution.

Plankton were sampled by vertical tows of a $95 \mu \mathrm{m}$ mesh $0.5 \mathrm{~m}$ diameter plankton net. These tows were made at least in duplicate 2 or more hours after sunset
Brower \& Zar (1977)] for the assemblages captured simultaneously by reentry trapping and vertical net tows were always low, indicating the very different taxonomic composition of the demersal zooplankton and holozooplankton. In general, the demersal zooplankton was dominated by harpacticoid and cyclopoid copepods, copepod nauplii, and nematodes. In some cases (see below) cumaceans, gammarid amphipods, and mysids were dominant. The holozooplankton was dominated by calanoid and cyclopoid copepods, ostracods, chaetognaths, and larvaceans.

Significantly more demersal zooplankton were captured in overnight trap deployments than in the daytime in 2 direct comparisons (Table 1). Also, significantly more demersal zooplankton were associated with soft substrates than with hard substrates in a direct comparison (Table 1).

Large demersal forms (cumaceans, gammarid amphipods, and mysids) were relatively more abundant at soft substrate sites and at night than at sites with hard bottom substrate or during the day. These taxa constituted $82 \%$ of the demersal zooplankton at the deep site vs only $5 \%$ at the 23 -mile site in April 1985. They also represented $23 \%$ of the demersal zooplankton caught by day but $33 \%$ of those caught at night at the 6-mile site in August 1984. 
populations we sampled may be supported by the abundant and productive benthic microalgae populations found in Onslow Bay (Cahoon \& Cooke in press).

The abundance and distribution of demersal zooplankton may be controlled by planktivores, especially fishes. Our comparisons of demersal zooplankton abundances by day and night and between soft and hard substrate habitats show that fewer demersal zooplankton enter the water by day and that fewer and smaller demersal zooplankton are captured over hard substrates (Table 1). The demersal zooplankton sampled at the deep site, with little relief and few associated fishes, was dominated by large animals, but smaller zooplankters dominated at the 23-mile site, which supports numerous planktivorous fishes (Clavijo et al. 1989). These results suggest that visually orienting and/or tactile planktivores associated with hard substrate habitats feed readily on at least some demersal taxa, and may explain why so many of the abundances reported by others from such hard substrate communities are mostly lower than ours (Table 2).

Soft substrates are prevalent in Onslow Bay, so the relatively high numbers of demersal zooplankton associated with them argue that demersal zooplankton are an important component of this continental shelf ecosystem. Currents may transport demersal zooplankton into hard bottom habitats, making them available to resident planktivores. Planktivores may forage over soft bottom habitats (Bolden 1990, Bell \& Coull 1978). Predatory holozooplankters are also likely to feed on migrating demersal zooplankters. Thus, there may be several links between demersal zooplankton and higher trophic levels in the continental shelf ecosystem.

Acknowledgements. This research was supported by the NOAA/NURC-UNCW (\#NA80AA-H-00081/\#NA88AAD-UR004), UNC Sea Grant (R/MG 84-07 and R-MRR-88-01), NSF RII 8311 486, the American Philosophical Society, the Lerner-Grey Fund for Marine Research, and the N.C. Collegiate Academy of Sciences. We thank the crew of RV 'Seahawk', the NURC-UNCW diving staff, D. Freeman, S. Banner, and C. Amsler. This is contribution \# 046 of the Center for Marine Science Research at UNC Wilmington.

\section{LITERATURE CITED}

Alldredge, A. L., King, J. M (1977). Distribution, abundance, and substrate preferences of demersal reef zooplankton at Lizard Island Lagoon, Great Barrier Reef. Mar. Biol. 41 : $317-333$

Alldredge, A. L., King, J. M. (1980). Effects of moonlight on the temporal migration patterns of demersal zooplankton. J. exp. mar. Biol. Ecol. 44: 133-156

Bell, S. S., Coull, B. C. (1978). Field evidence that shrimp predation regulates meiofauna. Oecologia 35: 141-148

Bolden, S. K. (1990). Abundance, diet, and foraging migrations of the tomtate (Haemulon aurolineatum) on an artificial and a natural reef in Onslow Bay, North

This note was submitted to the editor
Carolina. M.S. thesis, UNC Wilmington, Wilmington

Brower, J. E., Zar, J. H. (1977). Field and laboratory methods for general ecology. Wm. C. Brown Co., Dubuque, IA

Cahoon, L. B., Cooke, J. E. (1992). Benthic microalgal production in Onslow Bay, North Carolina, USA. Mar. Ecol. Prog. Ser. 84: 185-196

Cahoon, L. B., Lindquist, D. G., Clavijo, I. E., Tronzo, C. R. (1992). Sampling small invertebrates in the sediment-water interface. In: Cahoon, L. B. (ed.) Diving for Science....1992. American Academy of Underwater Sciences, Costa Mesa, CA. p. 51-59

Cahoon, L. B., Tronzo, C. R. (1988). A comparison of demersal zooplankton collected at Alligator Reef, Florida, using emergence and reentry traps. Fish. Bull. U.S. 86: 838-845

Cahoon, L. B., Tronzo, C. R. (1990). New records of amphipods and cumaceans in demersal zooplankton collections from Onslow Bay, North Carolina. J. Elisha Mitchell Sci. Soc. 106: 78-84

Clavijo, I. E., Lindquist, D. G., Bolden, S. K., Burk, S. W. (1989). Diver inventory of a midshelf reef fish community in Onslow Bay, North Carolina: preliminary results for 1988 and 1989. In: Lang, M. A., Jaap, W. C. (eds.) Diving for Science... 1989. Proceedings of the American Academy of Underwater Sciences Ninth Annual Scientific Diving Symposium, Costa Mesa, CA, p. 59-65

Hammer, R. M. (1981). Day-night differences in the emergence of demersal zooplankton from a sand substrate in a kelp forest. Mar. Biol. 62: 275-280

Hobson, E. S., Chess, J. R. (1979). Zooplankters that emerge from the lagoon floor at night at Kure and Midway Atolls, Hawaii. Fish. Bull. U.S. 77: 275-280

Jacoby, C. A., Greenwood, J. G. (1988). Spatial, temporal, and behavioral patterns in emergence of zooplankton in the lagoon of Heron Reef, Great Barrier Reef, Australia. Mar. Biol. 97: 309-328

McWilliams, P. S., Sale, P. F., Anderson, D. T (1981). Seasonal changes in resident zooplankton sampled by emergence traps in One Tree Lagoon, Great Barrier Reef. J. exp. mar. Biol. Ecol. 52: 185-203

Menzies, R. J., Pilkey, O. H., Blackwelder, B. W., Dexter, D., Huling, P., McCloskey, L. (1966). A submerged reef off North Carolina. Int. Rev. ges. Hydrobiol. 51: 393-431

Newton, J. G., Pilkey, O. H., Blanton, J. O. (1971). An oceanographic atlas of the North Carolina continental margin. N.C. Board of Science and Technology, Raleigh

Paffenhöfer, G.-A. (1985). The abundance and distribution of zooplankton on the southeastern shelf of the United States. In: Atkinson, L. P., Menzel, D. W., Bush, K. A. (eds.) Oceanography of the southeastern U.S. continental shelf. American Geophysical Union, Washington, D.C., p. $104-117$

Porter, J. W., Porter, K. G. (1977). Quantitative samplıng of demersal zooplankton migrating from different coral reef substrates. Limnol. Oceanogr. 22: 553-555

Robichaux, D. M., Cohen, A. C., Reaka, M. L., Allen, D. (1981). Experiments with zooplankton on coral reefs, or will the real demersal zooplankton please come up? P.S.Z.N. I: Mar. Ecol. 2: 77-94

Thomas, M. L., Jelley, E. (1972). Benthos trapped leaving the bottom in Bideford River, Prince Edward Island. J. Fish Res. Bd Can. 29: 1234-1237

Tronzo, C. R., Cahoon, L. B. (1989). A list of demersal zooplankton collected in Onslow Bay, North Carolina, USA. Plankton Newsletter 11. 14-18

Youngbluth, M. J. (1982). Sampling demersal zooplankton: a comparison of field collections using three different emergence traps. J. exp. mar. Biol. Ecol. 61 111-124

Manuscript first received: July 22, 1992

Revised version accepted: August 17, 1992 